\title{
PEREMPUAN DALAM LINTASAN SEJARAH: MENEPIS ISU KETIDAKSETARAAN GENDER DALAM ISLAM
}

\author{
Lisnawati \\ UIN Sunan Kalijaga Yogyakarta \\ lisnawati.ngr@gmail.com
}

Received:15-06-2019; Revised:15-06-2019; Accepted: 17-06-2019

\section{ABSTRACT}

Culture and civilization of the world that existed before the advent of Islam, such as Greek, Roman, Indian, Jewish, Christian, and pre-Islamic Arabia none of those which place women in honor and dignity. The existence of women is seen as subordinate compared to men. Man superiority is very dominant, creating a social inequality that results in injustice and human rights abuses. Then Islam came to bring mercy to the universe. Islam organizes in such a way as human relationships and liberates women from the shackles of ignorance. The issue of gender equality is often cornering Islam, whereas in fact Islam is the first that have the idea of gender equality. Islam comes with rising women. Human is seen in his capacity as 'abdullāh, there is no difference between men and women, both have the potential and have equal opportunity to become ideal servants. Men and women also have same functions and roles in their capacity as khaliffah of Allah. They will be accountable for the tasks of the caliphate on earth in the same position in front of Allah.

Keywords: Islam, status of women, history

\section{INTISARI}

Kebudayaan dan peradaban dunia yang ada sebelum datangnya Islam, seperti Yunani, Romawi, India, Yahudi, Kristen, dan Arab pra Islam tidak satupun yang menempatkan perempuan pada status terhormat dan bermartabat. Keberadaan perempuan dipandang subordinat dibandingkan dengan laki-laki. Superioritas laki-laki sangat dominan, menjadikan ketimpangan sosial yang menghasilkan ketidakadilan dan pelanggaran hak asasi manusia. Kemudian Islam datang membawa rahmat bagi alam semesta. Islam mengatur sedemikian rupa relasi antarmanusia dan membebaskan kaum perempuan dari belenggu kejahiliahan. Isu kesetaraan gender sering kali memojokkan Islam, padahal sejatinya Islam adalah yang pertama kali memiliki gagasan kesetaraan gender. Islam datang dengan mengangkat derajat perempuan. Manusia dipandang dalam kapasitasnya sebagai 'abdulläh, tidak ada perbedaan antara laki-laki dan perempuan, keduanya berpotensi dan mempunyai peluang yang sama untuk menjadi hamba ideal. Laki-laki dan perempuan juga mempunyai fungsi dan peran yang sama dalam kapasitasnya sebagai khalīfah Allah. Mereka akan mempertanggungjawabkan tugas-tugas kekhalifahannya di bumi dalam posisi yang sama di hadapan Allah.

Kata Kunci: Islam, status perempuan, sejarah

\section{A. Pendahuluan}

Sebelum Islam datang, perempuan sangat menderita dan tidak memiliki kebebasan hidup yang layak. Pada masa peradaban Yunani misalnya, yang banyak melahirkan para filosof, tetapi status perempuan tidak mendapatkan perhatian. Begitu juga pada masa peradaban Romawi, 
perempuan sepenuhnya berada di bawah kekuasaan ayahnya, setelah kawin, kekuasaan tersebut pindah ke tangan sang suami. Pada masyakarat India, Yahudi, dan Kristen juga demikian, menempatkan perempuann pada derajat yang rendah.

Masyarakat Arab di masa pra Islam pun tidak jauh berbeda dengan peradaban-peradaban lainnya saat itu, bahkan dikenal dengan istilah masyarakat Jahiliah, yang mana seorang ayah boleh saja membunuh anaknya yang sekiranya lahir perempuan. Pada zaman itu ada keyakinan bahwa setiap anak perempuan yang lahir harus dibunuh, karena khawatir nantinya akan kawin dengan orang asing atau orang yang berkedudukan sosial rendah, misalnya budak atau mawāli. ${ }^{1}$

Islam kemudian datang sebagai rahmat bagi alam semesta. Secara bertahap perempuan dinaikkan derajatnya sehingga sejajar dengan laki-laki. Namun demikian, tidak dapat dipungkiri ada sebagian kalangan yang memojokkan Islam dengan isu gender, karena dipandang bias gender. Padahal Islamlah yang pertama kali menggagas kesetaraan gender dalam sejarah manusia. Ketika Islam dipahami secara parsial maka akan menghasilkan pemahaman yang sempit dan keliru. Oleh sebab itu, dalam tulisan ini penulis akan membahas secara mendalam permasalahan status perempuan dalam sejarah Islam, yang dimulai dengan status perempuan pra Islam, status perempuan setelah Islam datang, dan terkait isu ketidaksetaraan gender yang ditujukan pada Islam.

\section{B. Metode Penelitian}

Jenis penelitian ini ialah penelitian kepustakaan. Data dikumpulkan dengan menggunakan teknik penelaahan terhadap teori-teori, konsep-konsep, generalisasi-generalisasi yang dapat dijadikan landasan teoretis bagi penelitian. ${ }^{2}$ Penelitian ini bersifat deskriptif ${ }^{3}$ dan menggunakan pendekatan historis (historical approach). ${ }^{4}$ Sedangkan metode analisis data menggunakan metode analisis isi (content analysis).

\section{Hasil dan Pembahasan}

\section{Status Perempuan Pra Islam}

Berdasarkan catatan sejarah, sebelum datangnya Islam, dunia telah memiliki beberapa peradaban besar, di antaranya Yunani, Cina, India, Romawi, Persia dan Mesir. Dalam peradaban tersebut, status perempuan selalu mengalami perubahan. Meskipun adakalanya mereka dihormati, tetapi berbagai penindasan dan perlakuan negatif seringkali menimpa kehidupan kaum perempuan. Banyak orang yang tidak memiliki rasa kemanusiaan terhadap perempuan dengan berbagai alasan, karena tradisi ataupun adat. ${ }^{5}$ Demikianlah gambaran mengenai status perempuan dalam sejarah.

Status perempuan pra Islam dapat dibagi menjadi beberapa pokok bahasan. Pertama, status perempuan pada masa Yunani Kuno. Pada masyarakat Yunani banyak melahirkan para pemikir (filosof), namun tidak banyak menyinggung masalah hak dan kewajiban perempuan. Perempuan

\footnotetext{
${ }^{1}$ Agustin Hanapi, "Peran Perempuan dalam Islam", Gender Equality, Vol. 1, No. 1, Maret 2015, h. 16.

${ }^{2}$ Sumadi Suryabrata, Metode Penelitian, cet. XXI, Jakarta: Rajawali Pers, 2015, h. 18.

${ }^{3}$ Penelitian yang bersifat deskriptif ini secara umum memiliki tujuan untuk menggambarkan secara sistematik dan akurat fakta dan karakteristik mengenai bidang tertentu. Lihat Suteki dan Galang Taufani, Metodologi Penelitian: Filsafat, Teori dan Praktik, Depok: Rajawali Pers, 2018, hlm. 133.

${ }^{4}$ Pendekatan historis dilakukan dengan menelaah latar belakang apa yang dipelajari dan perkembangan pengaturan mengenai isu yang dihadapi. Telaah demikian diperlukan oleh peneliti manakala peneliti memang ingin mengungkap filosofis dan pola pikir yang melahirkan sesuatu yang sedang dipelajari. Lihat Peter Mahmud Marzuki, Penelitian Hukum, Jakarta: Kencana, 2011, hlm. 134-135.

${ }^{5}$ Tri Handayani dan Deddy Ilyas, "Isu Gender: Potret Relasi Lampau, at A Glance", Jurnal Ilmu Agama (JIA), Vol. 14, No. 1, Juni 2013, h. 3.
} 
diklasifikasikan menjadi tiga macam yaitu: (1) Para pelacur yang semata bertugas sebagai pemuas nafsu laki-laki; (2) Selir-selir yang tugasnya merawat tubuh dan kesehatan tuannya; (3) Para istri yang bertugas merawat dan mendidik anak-anak, seperti para pengasuh anak atau babysitter saat ini. ${ }^{6}$

Kedua, status perempuan pada masa Romawi. Masyarakat Romawi terbiasa memandang istri seperti balita atau anak remaja yang harus selalu diawasi. Perempuan selalu di bawah perlindungan dan pengawasan suaminya. Selama masa itu, bila seorang perempuan menikah, maka dia dan segala miliknya berada di bawah kekuasaan suami. Tidak hanya itu, suami juga mengambil alih hak-hak istri. Apabila seorang istri melakukan suatu kesalahan, maka adalah hak suami untuk menjatuhkan hukuman baginya. Seorang suami bahkan berhak memvonis mati terhadap istrinya. Seorang istri di Roma tidak lebih sekadar barang koleksi (perabot) milik suami. Jadi, kedudukannya sebanding dengan seorang budak yang semata-mata tugasnya menyenangkan dan menguntungkan tuannya. Dia tidak diizinkan untuk mengambil bagian dalam segala persoalan, baik yang bersifat pribadi maupun kemasyarakatan, dengan kata lain, dia tidak berhak menerima surat kuasa, saksi, menjadi penjamin orang lain dan bahkan menjadi wali. Apabila suaminya meninggal, maka semua anak laki-lakinya (baik kandung maupun tiri), terutama saudara laki-lakinya berhak atas dirinya. ${ }^{7}$

Ketiga, status perempuan di India. Peraturan yang berhubungan dengan masalah faraid (pembagian hak waris) hanya diturunkan melalui garis laki-laki saja dan tidak pada perempuan. Perempuan dipandang sebagai sumber dosa dan sumber dari kerusakan akhlak dan agama. Seorang istri di India terbiasa memanggil suaminya dengan "yang mulia", atau bahkan "Tuhan", karena laki-laki memang dipandang sebagai penguasa bumi. Seorang istri tidak pernah diajak makan bersama dengan suaminya. Dia harus memuja suaminya, dia juga harus melayani ayah dari suaminya, karena perempuan dianggap barang milik suami, dan dia harus tunduk pula kepada anak-anaknya. ${ }^{8}$ Bahkan saat suaminya meninggal dunia, maka istrinya harus ikut dibakar hidup-hidup bersama mayat suaminya. ${ }^{9}$

Keempat, status perempuan pada masyarakat Yahudi. Beberapa kepercayaan Yahudi memandang perempuan sebagai makhluk yang lebih rendah dibandingkan laki-laki bahkan menganggap perempuan lebih rendah kedudukannya daripada khadam (pembantu) laki-laki. Perempuan tidak mendapatkan warisan apapun dari orang tuanya, bila dirinya masih memiliki saudara laki-laki. Ayahnya berhak untuk menjual dirinya jika telah menginjak dewasa. Apabila seorang perempuan memutuskan untuk menikah, maka semua miliknya menjadi milik suaminya. Seorang suami memiliki hak penuh atas milik istri selama mereka terikat dalam ikatan pernikahan. Jika ia menemukan suaminya di tempat tidur bersama perempuan lain, maka dia harus tetap diam dan tidak boleh mengeluh. Hal ini disebabkan suami mempunyai hak penuh atas dirinya, suami dapat berbuat sesuka hatinya. ${ }^{10}$

Kelima, status perempuan pada masyarakat Kristen. Pandangan Kristen tentang perempuan, hasil dari konferensi agama Kristen pada abad ke-5 merumuskan bahwa perempuan itu tidaklah mempunyai jiwa dan kediamannya adalah di neraka. Hanya ada satu kekecualian yaitu terhadap Maryam, ibunda Isa al-Masih. Seabad kemudian, konferensi yang lain digelar

${ }^{6}$ R. Magdalena, "Kedudukan Perempuan dalam Perjalanan Sejarah (Studi tentang Kedudukan Perempuan dalam Masyarakat Islam", Al- 'Ulum, Vol. 2, 2013, h. 44.

${ }^{7}$ Ibid., h. 45.

${ }^{8}$ Ibid.

${ }^{9}$ Tri Handayani dan Deddy Ilyas, "Isu Gender...”, h. 3.

${ }^{10}$ R. Magdalena, "Kedudukan Perempuan...”, h. 45. 
dengan mengambil topik bahasan hakikat perempuan, apakah dia itu manusia atau bukan. Mereka akhirnya sampai pada satu titik kesimpulan bahwa perempuan adalah manusia. Perempuan diciptakan sebagi pelayan dan untuk keuntungan kaum laki-laki. ${ }^{11}$ Jamal A. Badawi mengutip pernyataan David dan Vera Mace dalam Marriage East And West sebagai berikut:

Jangan biarkan orang beranggapan, bahwa warisan ajaran Kristen kita pun bebas dari pandangan yang meremehkan seperti itu. Sulit untuk menemukan dimana pun sejumlah keterangan yang merendahkan kaum perempuan seperti yang disampaikan oleh para gerejawan di masa awal. Lecky, seorang sejarawan terkemuka, berbicara mengenai (dorongan kuat ini yang membentuk tulisan para Pendeta sangat menyolok dan perempuan digambarkan sebagai pintu neraka. Sebagai induk dari semua kesalahan manusia. Dia harusnya merasa malu dengan hanya dengan berpikir bahwa dia seorang perempuan. Dia harus selalu hidup dalam penebusan dosa sebagai akibat dari kutukan yang dibawanya ke dunia. Dia harus merasa malu terhadap pakaiannya, karena itu adalah kenangan terhadap kesalahannya. Terlebih lagi dia harus merasa malu dengan kecantikannya, karena itu adalah alat yang paling kuat bagi setan). Salah satu yang paling melukai dari seranganserangan terhadap perempuan adalah Tertullianus. Tahukan anda bahwa setiap anda adalah Hawa? Ketetapan Tuhan atas jenis kalian hidup di masa ini, dan kesalahan pun tetap hidup. Engkau adalah jalan setan; engkaulah yang membuka jalan ke pohon terlarang itu, dan engkau adalah pembangkang pertama terhadap hukum yang telah ditetapkan; engkaulah yang membujuknya (laki-laki) ketika setan tidak mampu menyerangnya. Engkau menghancurkan gambaran Tuhan, laki-laki, dengan mudah. Dikarenakan penghianatanmu - kematian - bahkan tatanan Tuhan pun harus mati). Tidak saja gereja menegaskan kedudukan rendah perempuan, ia juga mencabut hak-haknya yang telah dinikmati sebelumnya. ${ }^{12}$

Tampaknya kedudukan perempuan dalam masyarakat Kristen selalu dikaitkan dengan sejarah asal mula kejadiannya. Perempuan dianggap telah bersalah sehingga diusir dari surga dan dosa ini terus diwariskan pada keturunan berikutnya. Meskipun dewasa ini hal demikian sudah berubah. Namun, catatan sejarah menunjukkan bahwa peradaban-peradaban besar sebelum Islam datang memandang perempuan berada pada subordinatif yang sangat minim diberikan hakhaknya bahkan cenderung dizalimi.

Keenam, status perempuan pada masyarakat Arab. Di masyarakat Arab pada masa pra Islam terdapat beberapa kebudayaan Jahiliah, salah satunya yaitu kebiasaan membunuh anak perempuan. M. Quraish Shihab menyebutkan tiga alasan terjadinya pembunuhan pada zaman Jahiliah. Pertama, orang tua pada masa masyarakat Jahiliah takut jatuh miskin bila menanggung biaya hidup anak perempuan yang dalam konteks zaman itu, tidak bisa mandiri dan produktif. Kedua, masa depan anak-anak dikhawatirkan mengalami kemiskinan (jatuh miskin). Anak perempuan dikubur karena orang tuanya khawatir anak-anak perempuan diperkosa atau berzina. Ketiga, sesuai dengan seringnya konflik antarkabilah atau peperangan antarsuku, orang tua khawatir anaknya akan ditawan musuh dalam peperangan itu. ${ }^{13}$

\footnotetext{
${ }^{11}$ Ibid., h. 46.

${ }^{12}$ Jamal A. Badawi, Kedudukan Wanita dalam Islam (The Status of Woman in Islam), Ebook, terj. Ummu Abdullah, dalam Maktabah Raudhah al Muhibbin, http://raudhatul muhibbin.blogspot.com, 2008, diakses tanggal 13 Maret 2018, h. 6.

${ }^{13}$ Viky Mazaya, "Kesetaraan Gender dalam Perspektif Sejarah Islam”, SAWWA, Vol. 9, No. 2, April 2014, h. 329.
} 
Masyarakat Jahiliah beralasan bahwa anak perempuan adalah biang dari petaka karena dari segi fisik perempuan lebih lemah daripada laki-laki. Ketika lemah, secara otomatis akan menjadi batu sandungan bagi sang ayah atau ketua kelompok dan tidak bisa diajak berperang. Selain itu, juga akan mengurangi pengaruh kabilahnya dalam percaturan dunia, penghambat pembangunan, kurang bisa mandiri dan menggantungkan pada laki-laki, itu semua adalah aib bagi mereka maka harus ditutupi kalau perlu dibuang. Dengan fenomena tersebut, hak-hak perempuan tidak terpenuhi bahkan tidak akan terpenuhi. ${ }^{14}$

Zamakhsyari memberi komentar atas fenomena di masyarakat Arab pra Islam yang apabila bayi perempuan yang lahir maka akan ditanam hidup-hidup, bahwa pada masa tersebut anak perempuan yang akan ditanam hidup-hidup diminta agar ibunya menghiasinya terlebih dahulu dengan alasan akan dibawa menemui keluarganya. Setibanya di tempat yang dituju dan setelah lubang digali ia menyuruh anak tersebut melihat ke lubang itu, lalu dijerumuskan, dan ditanam hidup-hidup. Biasanya anak peremuan tersebut telah mencapai umur enam tahun. Ada juga ibuibu yang sengaja melahirkan di depan sebuah lubang yang disiapkan terlebih dahulu dan bila ternyata anaknya perempuan langsung saja menanamnya hidup-hidup di lubang yang telah disiapkan. ${ }^{15}$ Menurut Shihab, catatan terpenting yang ingin ia sampaikan ialah bahwa tradisi mengubur anak perempuan hidup-hidup bukan adat yang memperoleh restu dari semua kabilah Arab Jahiliah. ${ }^{16}$ Kendati demikian, kebiasaan mengubur anak perempuan menjadi hal yang lumrah bagi masyarakat Arab pra Islam.

Adat istiadat Jahiliah yang berlaku pada masa pra Islam, selain mengubur hidup-hidup setiap anak perempuan yang dilahirkan, yaitu mengawini perempuan sebanyak yang disukai dan menceraikan mereka sesuka hati. Sebagaimana dimaklumi, masyarakat Arab zaman Jahiliah mempraktikkan bermacam-macam pola perkawinan. Ada yang disebut nikāhh ad-dayzān, di mana anak sulung laki-laki dibolehkan menikahi janda (istri) mendiang ayahnya. Cukup dengan melemparkan sehelai kain kepada janda dari ayahnya itu, maka saat itu juga dia sudah mewarisi ibu tirinya itu sebagai istri. Kadangkala dua orang bapak saling menyerahkan putrinya masingmasing kepada satu sama lain untuk dinikahinya, praktik ini dinamakan nikāh asy-syigār. Ada pula yang saling bertukar istri hanya dengan kesepakatan kedua suami tanpa perlu membayar mahar, yaitu nikāḥ al-badāl. Selain itu ada pula yang dinamakan zawāj al-istibdă', di mana seorang suami boleh dengan paksa menyuruh istrinya untuk tidur dengan lelaki lain sampai hamil dan setelah hamil sang istri dipaksa untuk kembali kepada suaminya semula, semata-mata karena mereka ingin mendapatkan bibit unggul dari orang lain yang dipandang mempunyai keistimewaan tertentu. Ada juga jenis pernikahan yang disebut dengan nikăḥ al-mukhädanah, yaitu pernikahan seorang perempuan yang mempunyai banyak suami (poliandri). Hal seperti ini banyak terjadi antarsaudara di kalangan bangsa Arab. ${ }^{17}$ Praktik-praktik yang dilakukan pada masa pra Islam menunjukkan ketidakberdayaan perempuan, yang seakan-akan tidak dianggap selayaknya manusia. Baik jiwanya lebih-lebih harga diri dan hak-haknya dianggap tidak berharga.

\section{Status Perempuan pada Masa Islam}

Pada periode awal Islam, Nabi Muhammad SAW menyebarkan ajaran Islam secara universal kepada seluruh manusia, di bawah bimbingan wahyu Allah SWT. W.M. Watt merinci ajaran Islam yang diajarkan oleh Nabi Muhammad SAW pada periode awal Islam tersebut ke

\footnotetext{
${ }^{14} \mathrm{Ibid}$.

${ }^{15}$ Ali Nurdin, Quranic Society, Jakarta: Erlangga, 2006, h. 39-40.

${ }^{16}$ Viky Mazaya, "Kesetaraan Gender...", h. 329.

${ }^{17}$ Ibid., h. 330-331.
} 
dalam 5 (lima) tema pokok, yaitu; kebaikan dan kekuasaan Tuhan (God's Goodness and Power), pengadilan Tuhan di akhirat (The Return to God for Judgement), respon manusia untuk bersyukur dan menyembah Tuhan (Man's Response-gratitude and worship), respon manusia di hadapan Tuhan untuk seorang dermawan (Man Response to God-Generosity) dan risalah kenabian Muhammad SAW (Muhammad's own vocation). Inti ajaran awal Nabi Muhammad SAW adalah ajaran tauhid, yaitu ajaran untuk beriman kepada Allah yang Maha Esa yang mengadili pertanggungjawaban seluruh makhluk-Nya (termasuk manusia) atas semua perbuatannya. ${ }^{18}$

Penegakan hak-hak dasar manusia khususnya perempuan dalam Islam, antara lain dilakukan melalui perbaikan hukum keluarga yang mencakup: Pertama, hak kepemilikan seperti perempuan berhak menerima waris, hak mahar bagi perempuan (istri) secara mutlak, hak mencari dan memperoleh karunia harta serta hak men-tașaruf-kannya secara mandiri; Kedua, hak memperoleh pendidikan dan pengajaran seperti belajar ilmu agama, meriwayatkan hadis, menyampaikan pesan-pesan agama baik ketika masih gadis maupun telah menikah; Ketiga, pembatasan poligami disertai dengan persyaratan yang ketat dan peringatan bagi pelaku poligami agar memperhatikan perlindungan terhadap hak-hak perempuan; Keempat, memberikan ramburambu tentang hak-hak reproduksi perempuan agar terjadi keseimbangan peran dan tanggungjawab perempuan dan laki-laki seperti hak menentukan pasangan, hak melakukan hubungan seksual, merencanakan keluarga sehat (kehamilan dan jarak kelahiran), merawat, dan mengasuh serta mendidik anak; Kelima, hak mensejahterakan keluarga dari aspek ekonomi, sosial dan mental, serta menghindari terjadinya kekerasan dalam rumah tangga. ${ }^{19}$

Selain yang telah disebutkan di atas dalam tradisi Islam, perempuan mukallaf dapat melakukan berbagai perjanjian, sumpah, dan nazar, baik kepada sesama manusia maupun kepada Tuhan, dan tidak ada suatu kekuatan yang dapat menggugurkan janji, sumpah, atau nazar mereka sebagaimana ditegaskan dalam QS. al-Mā'idah [5]: 89. ${ }^{20}$ Perempuan dan laki-laki mempunyai kedudukan yang sama di depan hukum, bahkan Islam memberikan hak yang sama kepada perempuan dalam mengakhiri kehidupan berumah tangga yaitu dengan cara khulü' Dalam Islam, laki-laki dan perempuan dianggap sebagai makhluk Allah yang setara, bebas ber-tașarruf, bahkan satu sama lain saling melengkapi dan membutuhkan. ${ }^{21}$ Islam telah mengatur sedemikian rupa relasi antarmanusia dan membebaskan kaum perempuan dari belenggu kejahiliahan.

Islam telah mengangkat derajat perempuan dari masa pencampakkan perempuan di era Jahiliah ke era kemuliaan perempuan. Islam tidak membedakan antara perempuan dan laki-laki. Semua sama di hadapan Allah SWT, dan yang membedakan mereka di hadapan Allah adalah mereka yang paling bertakwa. M. Atho' Mudzhar dan Khoiruddin Nasution dalam Hukum

\footnotetext{
${ }^{18}$ Amad Hanif Fahruddin, "Learning Socety Arab Pra Islam (Analisa Historis dan Demografis)”, KUTTAB, Vol. 1, No. 1, Maret 2017, h. 47-48.

${ }^{19}$ Mufidah (Ed.), Isu-isu Gender Kontemporer dalam Hukum Keluarga, Malang: UIN-Maliki Press, 2010, h. ix.

${ }^{20}$ Allah tidak menghukum kamu disebabkan sumpah-sumpahmu yang tidak dimaksud (untuk bersumpah), tetapi Dia menghukum kamu disebabkan sumpah-sumpah yang kamu sengaja, Maka kafarat (melanggar) sumpah itu, ialah memberi ,akan sepuluh orang miskin, yaitu dari makanan yang biasa kamu berikan kepada keluargamu, atau memberi pakaian kepada mereka atau memerdekakan seorang budak. barang siapa tidak sanggup melakukan yang demikian, Maka kafaratnya puasa selama tiga hari. yang demikian itu adalah kafarat sumpah-sumpahmu bila kamu bersumpah (dan kamu langgar). Dan jagalah sumpahmu. Demikianlah Allah menerangkan kepadamu hukumhukum-Nya agar kamu bersyukur (kepada-Nya). Lihat Kementerian Agama Republik Indonesia, Al-Qur'anulkarim Maqdis: Mushaf Al-Qur'an Tajwid dan Terjemah, Bandung: Cordoba Internasional-Indonesia, 2013, h. 122.

${ }^{21}$ Agustin Hanapi, "Peran Perempuan...", h. 16-17.
} 
Keluarga di Dunia Islam Modern sebagaimana dikutip oleh Ibnu Kasir, menyebutkan bahwa pada masa awal berdirinya Islam telah banyak perempuan-perempuan yang berjaya, mereka adalah Aisyah binti Abu Bakar (wafat $58 \mathrm{H}$ ), Hafsah binti Umar (wafat $45 \mathrm{H}$ ), Juwairiah binti Harits bin Abu Dhirar (wafat $56 \mathrm{H}$ ), Khadijah binti Khuwailid (wafat $3 \mathrm{SH}$ ), Maimunah binti Harits (wafat $50 \mathrm{H}$ ), Ummu Salamah (wafat $57 \mathrm{H}$ ), Zainab binti Jahsy (wafat $20 \mathrm{H}$ ), Fatimah binti Muhammad (wafat $11 \mathrm{H}$ ), Ummi Kultsum binti Muhammad (wafat $9 \mathrm{H}$ ), Zainab binti Muhammad (wafat $8 \mathrm{H}$ ), dan lain sebagainya. ${ }^{22}$ Secara konseptual, misi utama kenabian Muhammad SAW adalah untuk kerahmatan seluruh alam. Prinsip kerahmatan ini secara konseptual menjadi dasar peletakan fondasi pembahasan hukum Islam dan bangunan etika dalam berelasi antarsesama. Seperti perlunya berbuat baik, memberikan manfaaat, saling membantu, pengharaman menipu, pelarangan tindak kekerasan, dan penghapusan segala bentuk kezaliman. ${ }^{23}$ Islam dengan prinsip rậmatan lil- 'älamīn telah mengangkat derajat kaum perempuan, sehingga segala bentuk kezaliman yang dilakukan masyarakat Jahiliah terhadap perempuan merupakan hal yang bertentangan dengan misi kenabian tersebut.

\section{Menepis Isu Ketidaksetaraan Gender dalam Islam}

Gender adalah konsep yang menunjukkan kepada sistem peranan dan hubungan antara perempuan yang tidak ditentukan oleh perbedaan biologis, tetapi ditentukan oleh lingkungan sosial, politik, ekonomi dan budaya. ${ }^{24}$ Adapun dalam Kamus Hukum, disebutkan bahwa Gender adalah perbedaan sifat, peran, fungsi dan status antara laki-laki dan perempuan dengan tidak didasarkan pada perbedaan biologis, tetapi berdasarkan pada relasi sosial budaya yang dipengaruhi oleh struktur masyarakat yang lebih luas. ${ }^{25}$

Isu kesetaraan gender sering kali memojokkan Islam, padahal sejatinya Islamlah yang pertama kali memberikan gagasan kesetaraan gender. Islam datang dengan mengangkat derajat perempuan, yang ketika itu (zaman pra Islam) derajatnya sangat rendah. Islam memberikan hak seimbang antara laki-laki dan perempuan. Sekalipun terdapat perbedaan, hal itu karena perbedaan fungsi dan kewajiban masing-masing. Sehingga perbedaan tersebut tidak mengakibatkan antara laki-laki dan perempuan merasa memiliki kelebihan atas yang lain. Baik laki-laki dan perempuan, keduanya saling melengkapi untuk memerankan perannya sebagai khalifah di muka bumi. ${ }^{26}$ Allah SWT berfirman dalam surah an-Nisā' [4] ayat 32:

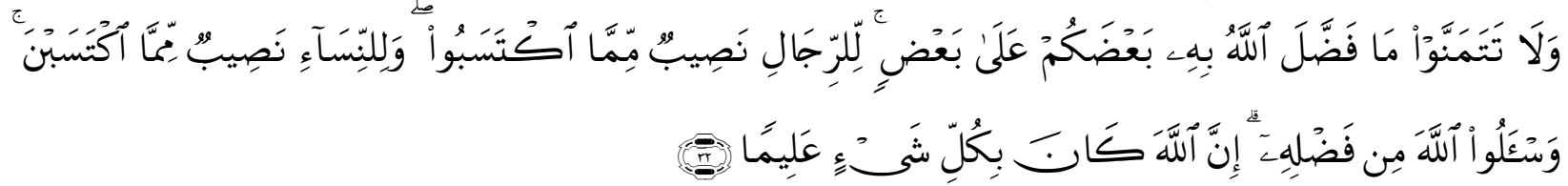

Artinya: Dan janganlah kamu iri hati terhadap karunia yang telah dilebihkan Allah kepada sebagian kamu atas sebagian yang lain. (karena) bagi laki-laki ada bagian dari apa yang mereka usahakan, dan bagi perempuan (pun) ada bagian dari apa yang mereka usahakan. Mohonlah ampun kepada Allah sebagian dari karunia-Nya. Sungguh, Allah Maha Mengetahui segala sesuatu.

${ }^{22}$ Ibnu Kasir, "Emansipasi Wanita dan Kesetaraan Gender dalam Pandangan Islam”, Harakat an-Nisa, Vol. 1, No. 1, Agustus 2016, h. 23-24.

${ }^{23}$ Anshori dan Siti Rahmah Aziz, Tafsir Tematik: Isu-isu Kontemporer Perempuan, Jakarta: PT. RajaGrafindo Persada, 2014, h. 52.

${ }^{24}$ Sofyan A.P. Kau, Fikih Alternatif, Yogyakarta: Mitra Pustaka, 2013, h. 182-183.

${ }^{25}$ M. Marwan, dan Jimmy P., Kamus Hukum, Yogyakarta: Gama Press, 2009, h. 221.

${ }^{26}$ Huzaemah Tahido Yanggo, Fikih Perempuan Kontemporer, Jakarta: Ghalia Indonesia, 2010, h. 91. 
Namun demikian, tetap saja ada sebagian orang yang mengkritik terhadap Islam karena dianggap bias gender. Di antara hal yang dikritik adalah masalah konsep kepemimpinan perempuan, aurat dan busana muslimah, persaksian, poligami, peran publik perempuan, dan konsep superiotas laki-laki. Nasaruddin Umar mengatakan, jika membaca sepintas beberapa ayat dan hadis terkait hal tersebut, selintas memang ada kecenderungan seolah Islam memojokkan perempuan dan mengistimewakan laki-laki. Tetapi jika ditelaah secara mendalam, maka justru sebaliknya, Islamlah yang pertama kali menggagas konsep keadilan gender dalam sejarah umat manusia. Di antara kebudayaan dan peradaban dunia yang hidup ketika waktu diturunkannya Alquran, seperti Yunani, Romawi, Yahudi, Persia, Cina, India, Kristen, dan Arab (pra-Islam), tidak ada satupun yang menempatkan perempuan lebih terhormat dan bermartabat daripada nilainilai yang diperkenalkan Alquran. ${ }^{27}$

Salah satu karakteristik hukum Islam adalah bercorak generalistik, yaitu untuk semua unsur manusia, menyatukan dalam ruang lingkup kebenaran dan memadukan dalam kebaikan. Hal tersebut ditunjukkan dengan tidak dibedakan suku, bangsa, bahasa, warna kulit, karena yang dipandang adalah ketakwaan dan amal baiknya. Allah memerintahkan, memotivasi dan mengingatkan supaya tidak meninggalkan keadilan sosial terutama dalam penetapan hukum dan menegakkan keadilan. ${ }^{28}$ Dalam Argumentasi Kesetaraan Jender Perspektif Al-Qur'an yang ditulis oleh Nasaruddin Umar, disebutkan ada beberapa variabel yang dapat digunakan sebagai standar dalam menganalisis prinsip-prinsip kesetaraan gender dalam Islam, yaitu:

a. Laki-laki dan Perempuan Sama-sama sebagai Hamba

Salah satu tujuan penciptaan manusia adalah untuk menyembah kepada Tuhan, sebagaimana disebutkan dalam QS. aż-Żāriyāt [51]: 56:

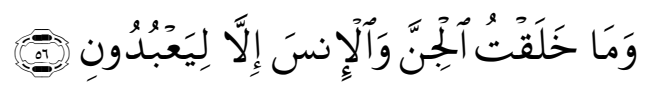

Artinya: Dan aku tidak menciptakan jin dan manusia melainkan supaya mereka mengabdi kepada-Ku. ${ }^{29}$

Dalam kapasitas manusia sebagai hamba, tidak ada perbedaan antara laki-laki dan perempuan. Keduanya mempunyai potensi dan peluang yang sama untuk menjadi hamba ideal. $^{30}$

b. Laki-laki dan Perempuan sebagai Khalifah di Bumi

Maksud dan tujuan penciptaan manusia di muka bumi ini adalah, di samping untuk menjadi hamba yang tunduk dan patuh serta mengabdi kepada Allah SWT, juga untuk menjadi khalifah di bumi. Kapasitas manusia sebagai khalifah di bumi ditegaskan di dalam QS. al-An'ām [6]: 165:

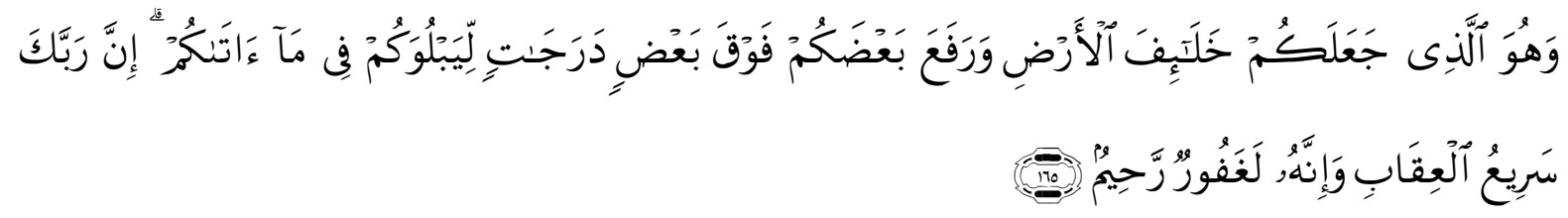

\footnotetext{
${ }^{27} I$ Ibid., h. v.

${ }^{28}$ Qurrotul Ainiyah, Keadilan Gender dalam Islam: Konvensi PBB dalam Perspektif Mazhab Syafi'i, Malang: Intrans Publishing, 2015, h. 32.

${ }^{29}$ Lihat Kementerian Agama Republik Indonesia, Al-Qur'anulkarim..., h. 523.

${ }^{30}$ Nasaruddin Umar, Argumentasi Kesetaraan Jender Perspektif Al-Qur'an, Jakarta Selatan: Paramadina, 1999, h. 248.
} 
Artinya: Dan Dialah yang menjadikan kamu penguasa-penguasa di bumi dan Dia meninggikan sebahagian kamu atas sebahagian (yang lain) beberapa derajat, untuk mengujimu tentang apa yang diberikan-Nya kepadamu. Sesungguhnya Tuhanmu amat cepat siksaan-Nya dan sesungguhnya Dia Maha Pengampun lagi Maha Penyayang. ${ }^{31}$

Kata khalïfah dalam ayat di atas tidak menunjuk kepada salah satu jenis kelamin atau kelompok etnis tertentu. Laki-laki dan perempuan mempunyai fungsi yang sama sebagai khalifah, yang akan mempertanggungjawabkan tugas-tugas kekhalifahannya di bumi, sebagaimana halnya mereka harus bertanggung jawab sebagai hamba Tuhan. ${ }^{32}$

c. Laki-laki dan Perempuan Menerima Perjanjian Primodial

Laki-laki dan perempuan sama-sama mengemban amanah dan menerima perjanjian primodial dengan Tuhan. Seperti diketahui, menjelang seorang anak manusia keluar dari rahim ibunya, ia terlebih dahulu harus menerima perjanjian dengan Tuhannya, sebagaimana disebutkan dalam QS. al-A'rāf [7]: 172:

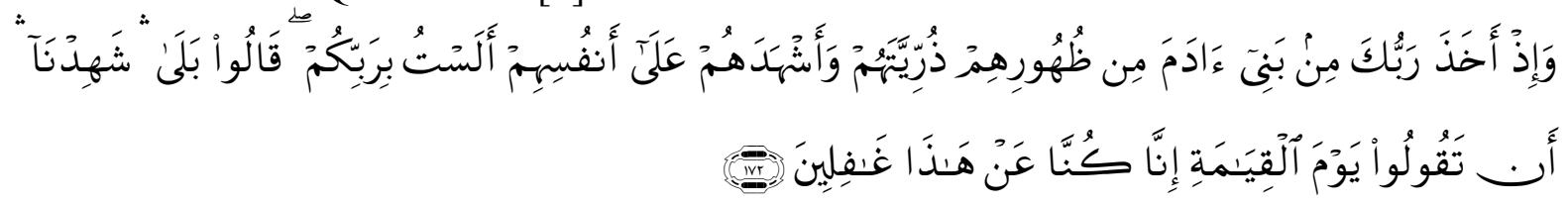

Artinya: Dan (ingatlah), ketika Tuhanmu mengeluarkan keturunan anak-anak Adam dari sulbi mereka dan Allah mengambil kesaksian terhadap jiwa mereka (seraya berfirman): "Bukankah Aku ini Tuhanmu?" Mereka menjawab: "Betul (Engkau Tuhan kami), kami menjadi saksi". (Kami lakukan yang demikian itu) agar di hari kiamat kamu tidak mengatakan: "Sesungguhnya kami (bani Adam) adalah orangorang yang lengah terhadap ini (keesaan Tuhan)". ${ }^{33}$

Menurut Fakhr ar-Rāzī sebagaimana yang dikutip oleh Umar, tidak ada seorang pun anak manusia lahir di muka bumi ini yang tidak berikrar akan keberadaan Tuhan, dan ikrar mereka disaksikan oleh para malaikat. Tidak ada seorang pun yang mangatakan "tidak". Dalam Islam, tanggung jawab individual dan kemandirian berlangsung sejak dini, yaitu semenjak dalam kandungan. Sejak awal sejarah manusia dalam Islam tidak dikenal adanya diskriminasi jenis kelamin. Laki-laki dan perempuan sama-sama menyatakan ikrar ketuhanan yang sama. ${ }^{34}$

d. Adam dan Hawa Terlibat secara Aktif dalam Drama Kosmis

Semua ayat yang menceritakan tentang drama kosmis, yakni cerita tentang keadaan Adam dan pasangannya di surga sampai keluar ke bumi, selalu menekankan kedua belah pihak secara aktif dengan menggunakan kata ganti untuk dua orang (humā), yakni kata ganti untuk Adam dan Hawa, seperti dapat dilihat dalam beberapa kasus berikut ini:

1) Keduanya diciptakan di surga dan memanfaatkan fasilitas surga.

2) Keduanya mendapat kualitas godaan yang sama dari setan.

3) Sama-sama memakan buah khuldi dan keduanya menerima akibat jatuh ke bumi.

4) Sama-sama memohon ampun dan sama-sama diampuni Tuhan.

\footnotetext{
${ }^{31}$ Lihat Kementerian Agama Republik Indonesia, Al-Qur'anulkarim..., h. 150.

${ }^{32}$ Nasaruddin Umar, Argumentasi..., h. 252-253.

${ }^{33}$ Lihat Kementerian Agama Republik Indonesia, Al-Qur'anulkarim..., h. 173.

${ }^{34}$ Nasaruddin Umar, Argumentasi..., h. 253-254.
} 
5) Setelah di bumi, keduanya mengembangkan keturunan dan saling melengkapi dan saling membutuhkan. ${ }^{35}$

e. Laki-laki dan Perempuan Berpotensi Meraih Prestasi

Peluang untuk meraih prestasi maksimum tidak ada pembedaan antara laki-laki dan perempuan, di antaranya ditegaskan secara khusus dalam ayat berikut:

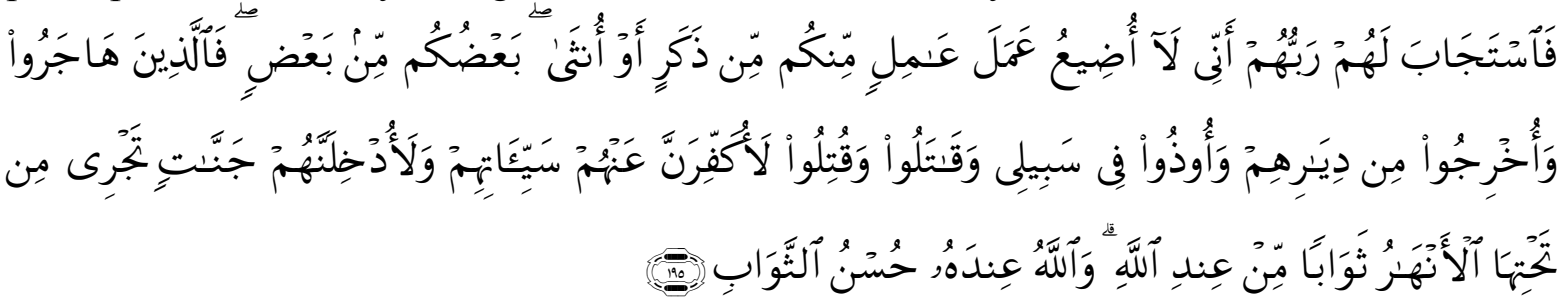

Artinya: Maka Tuhan mereka memperkenankan permohonannya (dengan berfirman): "Sesungguhnya Aku tidak menyia-nyiakan amal orang-orang yang beramal di antara kamu, baik laki-laki atau perempuan, (karena) sebagian kamu adalah turunan dari sebagian yang lain. Maka orang-orang yang berhijrah, yang diusir dari kampung halamannya, yang disakiti pada jalan-Ku, yang berperang dan yang dibunuh, pastilah akan Ku-hapuskan kesalahan-kesalahan mereka dan pastilah Aku masukkan mereka ke dalam surga yang mengalir sungai-sungai di bawahnya, sebagai pahala di sisi Allah. Dan Allah pada sisi-Nya pahala yang baik". (QS. Ali 'Imrān [3]: 195) $)^{36}$

Ayat tersebut di atas mengisyaratkan konsep kesetaraan gender yang ideal dan memberikan ketegasan bahwa prestasi individual, baik dalam bidang spiritual maupun urusan karier profesional, tidak mesti dimonopoli oleh salah satu jenis kelamin saja. Lakilaki dan perempuan memperoleh kesempatan yang sama meraih prestasi optimal. ${ }^{37}$

Sebagaimana penjelasan di atas pula, Alquran telah menegaskan bahwa Allah menciptakan manusia adalah untuk beribadah kepada-Nya. Dalam hal ini, maka manusia disebut 'abdullāh (hamba Allah). Manusia dalam kapasitasnya sebagai hamba, tidak ada perbedaan antara laki-laki dan perempuan, keduanya berpotensi dan mempunyai peluang yang sama untuk menjadi hamba ideal (muttaqin). Untuk mencapai derajat muttaqīn Alquran tidak pernah membedakan jenis kelamin, suku bangsa, atau kelompok etnis. Hamba Allah baik laki-laki maupun perempuan masing-masing akan mendapatkan penghargaan dari Allah sesuai dengan kadar pengabdiannya, bukan dari jenis kelaminnya. Kalaupun ada permasalahan-permasalahan yang memberikan kekhususan tertentu bagi laki-laki, itu pun tidak menjadikan laki-laki lebih utama (mulia) di hadapan Allah, yang menjadi pertimbangan sama sekali bukan karena laki-laki atau perempuan. Di samping manusia sebagai 'abdullāh, manusia juga sekaligus sebagai khalïfatullāh fil-arḍ (khalifah Allah di bumi). Kata Khalïfah dalam Alquran tidak menunjuk kepada salah satu jenis kelamin, bangsa, atau kelompok etnis tertentu. Laki-laki dan perempuan mempunyai fungsi dan peran yang sama dalam kapasitasnya sebagai khalīfah Allah. Mereka akan mempertanggungjawabkan tugas-tugas kekhalifahannya di bumi dalam posisi yang sama di hadapan Allah. Pada prinsipnya, tugas dan tanggung jawab manusia sebagai khaliffah Allah

\footnotetext{
${ }^{35}$ Ibid., h. 260-262.

${ }^{36}$ Lihat Kementerian Agama Republik Indonesia, Al-Qur'anulkarim..., h. 76.

${ }^{37}$ Nasaruddin Umar, Argumentasi..., h. 265.
} 
itu adalah menciptakan kemakmuran (mașlahat) dan menjaga serta melestarikan kemakmuran alam. ${ }^{38}$ Syariat Islam tidak membedakan manusia atas dasar jenis kelamin. Perbedaan peran dan fungsi tidak berarti terjadinya diskriminasi satu sama lain. Manusia, baik laki-laki maupun perempuan memiliki kesempatan yang sama meraih prestasi.

\section{E. Kesimpulan}

Kebudayaan dan peradaban dunia yang hidup ketika sebelum datangnya Islam, seperti Yunani, Romawi, India, Yahudi, Kristen, dan Arab tidak ada satupun yang menempatkan perempuan pada status terhormat dan bermartabat. Praktik-praktik yang dilakukan pada masa pra Islam menunjukkan ketidakberdayaan perempuan, yang seakan-akan tidak dianggap selayaknya manusia. Baik jiwanya lebih-lebih harga diri dan hak-haknya dianggap tidak berharga. Pada intinya, pada masa pra Islam perempuan sangat menderita dan tidak memiliki kebebasan hidup yang layak.

Islam datang sebagai rahmat bagi alam semesta. Islam telah mengangkat derajat perempuan dari masa pencampakkan perempuan. Islam tidak membedakan antara perempuan dan laki-laki, semua sama di hadapan Allah SWT dan yang membedakan mereka di hadapan Allah adalah mereka yang paling bertakwa. Namun, demikian tidak dapat dipungkiri ada sebagian kalangan yang memojokkan Islam dengan isu gender, karena dipandang bias gender. Isu kesetaraan gender sering kali memojokkan Islam. Padahal sejatinya Islamlah yang pertama kali memberikan gagasan kesetaraan gender. Islam datang dengan mengangkat derajat perempuan, yang ketika zaman pra Islam derajat perempuan sangatlah rendah. Islam memberikan hak seimbang antara laki-laki dan perempuan. Beberapa ayat Alquran mengisyaratkan konsep kesetaraan gender yang ideal dan memberikan ketegasan bahwa prestasi individual, baik dalam bidang spiritual maupun urusan karier profesional. Laki-laki dan perempuan memperoleh kesempatan yang sama meraih prestasi optimal.

\section{DAFTAR PUSTAKA}

Kementerian Agama Republik Indonesia, Al-Qur'anulkarim Maqdis: Mushaf Al-Qur'an Tajwid dan Terjemah, Bandung: Cordoba Internasional-Indonesia, 2013.

Ainiyah, Qurrotul, Keadilan Gender dalam Islam: Konvensi PBB dalam Perspektif Mazhab Syafi'i, Malang: Intrans Publishing, 2015.

Anshori dan Siti Rahmah Aziz, Tafsir Tematik: Isu-isu Kontemporer Perempuan, Jakarts: PT. RajaGrafindo Persada, 2014.

Badawi, Jamal A., Kedudukan Wanita dalam Islam (The Status of Woman in Islam), Ebook, terj. Ummu Abdullah, dalam Maktabah Raudhah al Muhibbin, http://raudhatulmuhibbin. blogspot.com, 2008, diakses tanggal 13 Maret 2018.

Fahruddin, Amad Hanif, "Learning Socety Arab Pra Islam (Analisa Historis dan Demografis)”, KUTTAB, Vol. 1, No. 1, Maret 2017.

Hanapi, Agustin, “Peran Perempuan dalam Islam”, Gender Equality, Vol. 1, No. 1, Maret 2015.

${ }^{38}$ Zainul Muhibbin, "Wanita dalam Islam”, Jurnal Sosial Humaniora (JSH), Vol. 4, No. 2, November 2011, h. $217-218$. 
Handayani, Tri dan Deddy Ilyas, "Isu Gender: Potret Relasi Lampau, at A Glance”, Jurnal Ilmu Agama (JIA), Vol. 14, No. 1, Juni 2013.

Kasir, Ibnu, "Emansipasi Wanita dan Kesetaraan Gender dalam Pandangan Islam", Harakat anNisa, Vol. 1, No. 1, Agustus 2016.

Kau, Sofyan A.P., Fikih Alternatif, Yogyakarta: Mitra Pustaka, 2013.

Magdalena, R., "Kedudukan Perempuan dalam Perjalanan Sejarah (Studi tentang Kedudukan Perempuan dalam Masyarakat Islam”, Al- 'Ulum, Vol. 2, 2013.

Marwan, M. dan Jimmy P., Kamus Hukum, Yogyakarta: Gama Press, 2009.

Marzuki, Peter Mahmud, Penelitian Hukum, Jakarta: Kencana, 2011.

Mazaya, Viky, "Kesetaraan Gender dalam Perspektif Sejarah Islam”, $S A W W A$, Vol. 9, No. 2, April 2014.

Mufidah (Ed.), Isu-isu Gender Kontemporer dalam Hukum Keluarga, Malang: UIN-Maliki Press, 2010.

Muhibbin, Zainul, "Wanita dalam Islam”, Jurnal Sosial Humaniora (JSH), Vol. 4, No. 2, November 2011.

Nurdin, Ali, Quranic Society, Jakarta: Erlangga, 2006.

Suryabrata, Sumadi, Metode Penelitian, cet. XXI, Jakarta: Rajawali Pers, 2015.

Suteki dan Galang Taufani, Metodologi Penelitian: Filsafat, Teori dan Praktik (Depok: Rajawali Pers, 2018.

Umar, Nasaruddin, Argumentasi Kesetaraan Jender Perspektif Al-Qur'an, Jakarta Selatan: Paramadina, 1999.

Yanggo, Huzaemah Tahido, Fikih Perempuan Kontemporer, Jakarta: Ghalia Indonesia, 2010. 